\title{
NEXT-GENERATION SEQUENCING OF DRUG RESISTANT MYCOBACTERIUM TUBERCULOSIS CLINICAL ISOLATES IN LOW-INCIDENCE COUNTRIES
}

\author{
E. Sodja ${ }^{a}$, N. Toplak ${ }^{b}$, S. Koren ${ }^{b}$, M. Kovač ${ }^{b}$, S. Truden ${ }^{a}$, M. Žolnir-Dovča \\ ${ }^{a}$ University Clinic of Respiratory and Allergic Diseases Golnik, Golnik, Slovenia \\ ${ }^{b}$ Omega d.o.o., Ljubljana, Slovenia
}

\begin{abstract}
Drug resistant tuberculosis (TB), especially multidrug (MDR) and extensively drug-resistant (XDR) TB, is still a serious problem in global TB control. Slovenia and North Macedonia are low-incidence countries with TB incidence rates of 5.4 and 10.4 in 2017, respectively. In both countries, the percentage of drug resistant TB is very low with sporadic cases of MDR-TB. However, global burden of drug-resistant TB continues to increase imposing huge impact on public health systems and strongly stimulating the detection of gene variants related with drug resistance in TB. Next-generation sequencing (NGS) can provide comprehensive analysis of gene variants linked to drug resistance in Mycobacterium tuberculosis. Therefore, the aim of our study was to examine the feasibility of a full-length gene analysis for the drug resistance related genes (inhA, $k a t G, r p o B$, embB) using Ion Torrent technology and to compare the NGS results with those obtained from conventional phenotypic drug susceptibility testing (DST) in TB isolates. Between 1996 and 2017, we retrospectively selected 56 TB strains from our National mycobacterial culture collection. Of those, 33 TB isolates from Slovenian patients were isolated from various clinical samples and subjected to phenotypic DST testing in Laboratory for Mycobacteria (University Clinic Golnik, Slovenia). The remaining 23 TB isolates were isolated from Macedonian patients and sent to our laboratory for assistance in phenotypic DST testing. TB strains included were either mono-, poly- or multidrug resistant. For control purposes, we also randomly selected five TB strains susceptible to first-line anti-TB drugs. High concordance between genetic (Ion Torrent technology) and standard phenotypic DST testing for isoniazid, rifampicin and ethambutol was observed, with percent of agreement of $77 \%, 93.4 \%$ and $93.3 \%$, sensitivities of $68.2 \%, 100 \%$ and $100 \%$, and specificities of $100 \%, 80 \%$ and $88.2 \%$, respectively. In conclusion, the genotypic DST using Ion Torrent semiconductor NGS successfully predicted drug resistance with significant shortening of time needed to obtain the resistance profiles from several weeks to just a few days.
\end{abstract}

Key words: tuberculosis, Mycobacterium tuberculosis, drug resistant tuberculosis, multidrug resistant tuberculosis, next-generation sequencing, Ion Torrent, phenotypic drug susceptibility testing.

\section{Адрес для переписки: \\ Содья Эва \\ Голник 36, 4204 Голник, Словения, Национальная референс- лаборатория, Университетская клиника респираторных и аллергических заболеваний. \\ Тел.: +386 42569 409. Факс: +386 42569117. \\ E-mail: eva.sodja@klinika-golnik.si}

\section{Библиографическое описание:}

Содья Э., Топлак Н., Корен С., Ковач М., Труден С., Жолнир-Довч М.

Секвенирование следующего поколения лекарственноустойчивых клинических изолятов Mycobacterium tuberculosis в странах с низким уровнем заболеваемости // Инфекция и иммунитет. 2019. Т. 9, № 5-6. C. $773-778$. doi: 10.15789/2220-7619-2019-5-6-773-778

(c) Sodja E. et al., 2019

\author{
Contacts: \\ Sodja Eva \\ Golnik 36, 4204 Golnik, Slovenia, National Reference Laboratory, \\ University Clinic of Respiratory and Allergic Diseases Golnik. \\ Phone: +386 42569 409. Fax: +386 42569117. \\ E-mail: eva.sodja@klinika-golnik.si
}

\section{Citation:}

Sodja E., Toplak N., Koren S., Kovač M., Truden S., Žolnir-Dovč M. Nextgeneration sequencing of drug resistant Mycobacterium tuberculosis clinical isolates in low-incidence countries // Russian Journal of Infection and Immunity = Infektsiya i immunitet, 2019, vol. 9, no. 5-6, pp. 773-778. doi: 10.15789/2220-7619-2019-5-6-773-778

DOI: http://dx.doi.org/10.15789/2220-7619-2019-5-6-773-778 


\title{
СЕКВЕНИРОВАНИЕ СЛЕДУЮЩЕГО ПОКОЛЕНИЯ ЛЕКАРСТВЕННОУСТОЙЧИВЫХ КЛИНИЧЕСКИХ ИЗОЛЯТОВ МYСОВАСТЕRIUM TUBERCULOSIS В CTPAHAХ С НИЗКИМ УРОВНЕМ ЗАБОЛЕВАЕМОСТИ
}

\author{
Содья Э. ${ }^{1}$, Топлак Н. ${ }^{2}$, Корен С. ${ }^{2}$, Ковач М. ${ }^{2}$, Труден С. ${ }^{1}$, Жолнир-Довч М. ${ }^{1}$ \\ ${ }^{1}$ Университетская клиника респираторных и аллергических болезней, Голник, Словения \\ ${ }^{2}$ Oтеgа d.o.о., Любляна, Словения
}

Резюме. Лекарственноустойчивый туберкулез (ЛУ-ТБ), особенно ТБ с множественной лекарственной устойчивостью (МЛУ-ТБ) и ТБ с широкой лекарственной устойчивостью (ШЛУ-ТБ), до сих пор представляет серьезную проблему глобального контроля ЛУ-ТБ. Словения и Северная Македония являются странами с низким низким уровнем заболеваемости ЛУ-ТБ, которые в 2017 г. составили 5,4 и 10,4 на 100 тыс. населения, соответственно. В обеих странах доля ЛУ-ТБ крайне низка, выявляются лишь спорадические случаи МЛУ-ТБ. Однако глобальный уровень ЛУ-ТБ продолжает расти, оказывая существенное влияние на систему здравоохранения, а также способствуя обнаружению генетических вариантов, связанных с ЛУ-ТБ. Секвенирование следующего поколения (next generation sequencing [NGS]) может предоставить возможность глубокого анализа генетических вариаций, ассоциированных с лекарственной устойчивостью Mycobacterium tuberculosis. Целью настоящего исследования была оценка применимости анализа таких генов (inh A, katG, rpoB, embB) с использованием технологии Ion Torrent и сравнения данных NGS и стандартного фенотипического определения лекарственной чувствительности (drug susceptibility testing [DST]) изолятов ЛУ-ТБ. Было проведено ретроспективное исследование 56 ЛУ-ТБ штаммов, полученных в течение 1996-2017 гг. из Национальной коллекции культур микобактерий (Голник, Словения). Из них, 33 изолята было получено от пациентов из Словении из различных клинических образцов, подвергнутых фенотипическому тестированию DST в Лаборатории микобактерий (University Clinic Golnik, Slovenia). Остальные 23 изолята были выделены от пациентов из Северной Македонии, и переданы в нашу лабораторию для помощи в проведении тестирования DST. ЛУТБ штаммы обладали моно-, поли- или множественной лекарственной устойчивостью. В качестве контрольных образцов были использованы случайным образом отобранные пять штаммов, чувствительных к противотуберкулезным препаратам первого ряда. В результате, показана высокая степень соответствия между генетическими (Ion Torrent) данными и результатами стандартного фенотипического DST для изониазида, рифампицина и этамбутола, с показателем согласия 77, 93,4 и 93,3\%, чувствительностью - 68,2, 100 и $100 \%$, специфичностью - 100, 80 и 88,2\% соответственно. Таким образом, генотипическое тестирование лекарственной устойчивости с применением NGS в формате полупроводниковой технологии Ion Torrent yспешно выявило лекарственную устойчивость с резким сокращением времени, необходимого для получения профиля резистентности - с нескольких недель до двух дней.

Ключевые слова: туберкулез, Мусовасtеrium tuberculosis, лекарственноустойчивый туберкулез, туберкулез с множественной лекарственной устойчивостью, секвенирование следующего поколения, Ion Torrent, фенотипическое определение лекарственной чувствительности.

\section{Introduction}

Mycobacterium tuberculosis (MT), an obligate pathogen that causes tuberculosis (TB), is highly transmissible agent with significant morbidity and mortality. Global strategies to treat and control TB are designed to accurately and rapidly diagnose, treat and reduce the transmission of TB. The increasing burden of multidrug resistant (MDR) and extensively drug-resistant (XDR) TB is a serious problem in global TB control. Slovenia and North Macedonia are countries with low incidence of TB cases with incidence rates 5.4 and 10.6 in 2017, respectively [1]. Moreover, in Slovenia in the period between 1996 and 2017 the average percentage of any drug resistance against isoniazid (INH), rifampicin (RIF), pyrazinamide (PZA), ethambutol (EMB) and streptomycin (SM) was $4.13 \%$, dropping from $6.55 \%$ in 1996 to $1.89 \%$ in 2017 . In the same period, 25 sporadic MDR-TB cases were observed with the last two cases of MDR-TB noted in 2009 and in 2017. For North Macedonia, the average percentage of any drug resistance against INH, RIF, EMB and SM (they do not perform DST testing for PZA) was higher and accounted for $10.84 \%$, dropping from $9.93 \%$ in 2001 to $5.81 \%$ in 2017. During 1996 and 201775 MDR-TB cases were observed in North Macedonia with MDRTB cases appearing each year $[2,3,4]$.

Currently, the reference method for determining drug resistance in clinical laboratory is culture based drug susceptibility testing (DST), using either solid or liquid media. However, this method is labour-intensive, time-consuming (due to slow growth of MT it takes weeks to months to obtain DST results), technically challenging and requires handling viable and potentially infectious cultures of MT bacilli [1].

As alternative to phenotypic DST, several commercially available molecular assays rapidly detect common mutations related to resistance to isoniazid, rifampicin and some second-line anti-TB 
drugs. GeneXpert MTB/RIF Ultra assay (Cepheid, Sunnyvale, CA, USA) is a real-time PCR based assay that detects resistance directly from sputum samples. On the other hand, there are several line probe assays recommended by WHO, including GenoType MTBDRplus and MTBDRsl (Hain Lifescience, Nehren, Germany) and Nipro NTM + MDRTB II (Nipro Corporation, Osaka, Japan). However, the mechanisms of drug resistance are complex and not completely understood. Therefore, one of the main limitations of such molecular tests is that they evaluate only limited number of mutations linked with drug resistance in TB [9].

In recent years, significant and continued progress in next-generation sequencing (NGS) made this technology a promising clinical tool in comprehensive analysis of gene variants linked to drug resistance in TB [9]. Besides known mutations, NGS facilitates the discovery of novel variants in the entire coding regions of several genes previously implicated in MDR and/or XDR-TB resistance [9].

In this study, we examined the feasibility of a fulllength gene analysis for the drug resistance related genes using Ion Torrent technology and compared the results with those obtained from conventional phenotypic drug susceptibility testing (DST) in 61
TB isolates. In this short paper, we compare molecular results with phenotypic DST results for isoniazid (INH), rifampicin (RIF) and ethambutol (EMB), anti-TB drugs used in first-line treatment regimens.

\section{Materials and methods}

TB strains. Between 1996 and 2017, we retrospectively selected 33 TB strains that were isolated from various clinical samples of Slovenian patients and subjected to phenotypic DST testing according to routine procedures in Laboratory for Mycobacteria (University Clinic Golnik, Slovenia). Between years 1999 and 2010, National Laboratory for Mycobacteria (Institute for Pulmonary Diseases and Tuberculosis Skopje, North Macedonia) sent to our laboratory 23 TB strains for assistance in phenotypic DST testing. TB strains included were either mono-, poly- or MDR resistant. For control purposes, we also randomly selected five TB strains susceptible to first-line anti-TB drugs. Detailed information about the type of resistance is presented in Table 1.

Phenotypic drug susceptibility (DST) testing. Phenotypic drug resistance to first-line drugs was determined using Bactec MGIT 960 System (BD) from pure culture of MT strains. Critical concentrations

Table 1. Distribution of Mycobacterium tuberculosis (MT) strains included in the study according to resistance profile and country of origin

\begin{tabular}{|c|c|c|c|}
\hline \multirow[b]{2}{*}{ Resistance profile } & \multicolumn{2}{|c|}{ Country of origin (survey period) } & \multirow[b]{2}{*}{ Number of TB patients } \\
\hline & $\begin{array}{c}\text { Slovenia } \\
(1996-2017) \\
\end{array}$ & $\begin{array}{c}\text { North Macedonia* } \\
(1999-2010)\end{array}$ & \\
\hline Sensitive & 5 & 0 & 5 \\
\hline Mono-resistance & 11 & 0 & 11 \\
\hline INH & 2 & 0 & 2 \\
\hline RIF & 3 & 0 & 3 \\
\hline PZA & 6 & 0 & 6 \\
\hline Poly-resistance & 6 & 1 & 7 \\
\hline PZA+SM & 3 & 0 & 3 \\
\hline INH+PZA+SM & 1 & 0 & 1 \\
\hline INH+PZA & 2 & 0 & 2 \\
\hline INH+EMB+PZA+SM+FLQ & 0 & 1 & 1 \\
\hline MDR & 16 & 22 & 38 \\
\hline INH+RIF & 1 & 7 & 8 \\
\hline INH+RIF+SM & 1 & 0 & 1 \\
\hline INH+RIF+EMB & 0 & 1 & 1 \\
\hline INH+RIF+PZA & 0 & 3 & 3 \\
\hline INH+RIF+EMB+PZA & 1 & 1 & 2 \\
\hline INH+RIF+EMB+SM & 2 & 3 & 5 \\
\hline INH+RIF+PZA+SM & 1 & 0 & 1 \\
\hline INH+RIF+EMB+PZA+SM & 8 & 6 & 14 \\
\hline INH+RIF+EMB+PZA+SM+FLQ & 2 & 1 & 3 \\
\hline Total & 38 & 23 & 61 \\
\hline
\end{tabular}

Notes. INH: Isoniazid; RIF: Rifampicin; EMB: Ethambutol; PZA: Pyrazinamide; SM: Streptomycin; FLQ: fluoroquinolones (either ofloxacin, ciprofloxacin or moxifloxacin); MDR: multi-drug resistance; resistance to (at least) INH and RIF; *National Laboratory for Mycobacteria (Institute for Pulmonary Diseases and Tuberculosis Skopje, North Macedonia) sent 23 TB strains for assistance in phenotypic DST testing. 


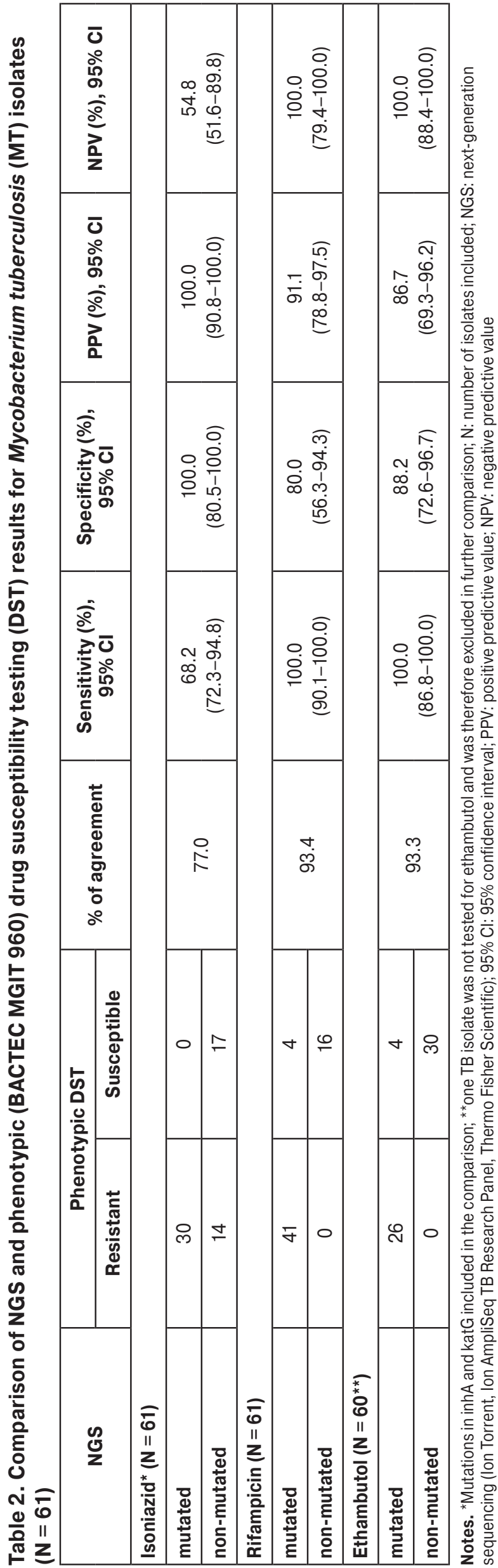

for anti-TB drugs tested were as follows: INH $0.1 \mu \mathrm{l} /$ $\mathrm{ml}$ (high level $0.4 \mu \mathrm{l} / \mathrm{ml}$ ), RIF $1 \mu \mathrm{l} / \mathrm{ml}$ and EMB $5 \mu \mathrm{l}$ / $\mathrm{ml}$ (high level $7.5 \mu \mathrm{l} / \mathrm{ml}$ ).

DNA extraction. Mycobacterial genomic DNA was isolated from pure cultures of $\mathrm{M}$. tuberculosis using previously described protocol [13]. Purified genomic DNA was stored at $-20{ }^{\circ} \mathrm{C}$ in Slovenian National Mycobacterial DNA Collection until further analysis.

AmpliSeq Library preparation, sequencing, data analysis and interpretation. Nucleic acid quality and quantity were assessed using NanoDrop 2000 (Thermo Scientific) followed by agarose gel electrophoresis. All DNA samples were normalized to $10 \mathrm{ng}$ in $15 \mu \mathrm{l}$ of starting sample dilution. To identify gene variants related with drug resistance in genomic DNA extracted from MT isolates, AmpliSeq libraries were generated using the AmpliSeq ${ }^{\mathrm{TM}} \mathrm{Kit}$ for Chef DL8 and the Ion AmpliSeq TB Research Panel. This panel amplifies 109 amplicons in two highly multiplexed PCR reactions covering coding sequences of eight genes related to drug resistance (including $i n h A$, kat $G, r p o B$, and $e m b B$ ). NGS libraries were prepared automatically using the Ion Chef instrument. The automated protocol performs targeted amplification, digestion, ligation, and normalization on eight samples without any user intervention. Prepared libraries were then automatically clonally amplified, enriched and sequenced on two Ion 530 Chips using the Ion Chef and Ion S5 instruments. Signal processing, base calling and variant caller analysis were performed with the Torrent Suite software version 5.6 (all reagents, instruments and software Thermo Fisher Scientific). The sequencing data were analysed manually, comparing the determined variants with published data and data available in the Tuberculosis Drug Resistance Database [7]. Sequence of MTB H37Rv (NC_000962.3) was used as the reference sequence. The resistance genotyping profiles obtained with manual approach were compared to the results of phenotypic DST testing. Sequence data are available in SRA NCBI database under BioProject accession number PRJNA551916.

Statistics. Sensitivity, specificity, positive predictive value (PPV) and negative predictive value (NPV) for NGS were calculated using GraphPad Prism v 6.04 (GraphPad Software, Inc., CA, USA).

\section{Results and discussion}

The NGS analysis was successfully used to predict drug resistance profiles. Percentage of agreement between both methods and corresponding sensitivities, specificities, positive predictive values and negative predictive values are presented in Table 2 .

The percent of agreement between molecular and phenotypic DST testing in our study was the lowest for INH and accounted for $77 \%$ with sensitivity of $68.2 \%$ and specificity of $100 \%$. The studies based 
on susceptibility testing so far have not demonstrated complete agreement between the phenotypic and genotypic assays $[6,7,12,14,16]$. Hazbon и соавт. [6] reported in their study on a large number of TB isolates that around $34 \%$ of phenotypically resistant isolates are not associated with any genotypic mutations in genes most commonly linked to INH resistance (kat $G$, inh $A, k a s A, a h p C$ and $n d h)$, suggesting that many genetic causes of INH resistance are yet to be discovered. Supporting this data, recent systemic review [12] on INH resistance demonstrated that $84 \%$ of global phenotypic INH resistance is associated with mutations in $k a t G$, inh $A$ and $a h p C$-oxyR intergenic region, while the other $16 \%$ are, probably, linked to genetic changes in other genes.

Our study indicates high percentage of agreement between both methods used for RIF resistance testing $(93.4 \%)$ with high sensitivity $(100 \%)$ and specificity $(80 \%)$. This is concordant with published literature $[5,10,13]$ which reported very good agreement between genotypic and phenotypic DST. Zaw et al. [15] showed that mutations in $r p o B$ gene (specifically mutations within 81-bp RIF-resistance determining region; RRDR) are responsible for approximately 95\% of all RIF resistance cases in TB strains.

Similarly, we also noticed high percent of agreement between phenotypic and genotypic DST results for EMB (93.3\%) with high sensitivity (100\%) and specificity $(88.2 \%)$. These results are concordant with some of the published studies [9, 10], which showed large overlap in the estimated prevalence of EMB resistance by genetic sequencing and the estimated prevalence by phenotypic testing. However, several other studies observed discrepancies between the presence of common mutations at codon 306 of $e m b B$ gene and phenotypic EMB resistance [5,
8]. Authors of these studies determined mutations in embB306 also in clinical M. tuberculosis isolates that are susceptible to EMB. One large study (with international TB isolates included) noted that almost half of the TB isolates with embB306 mutations were fully susceptible to EMB. Furthermore, they found strong correlation between embB306 mutations and resistance to any antibiotic, suggesting that embB306 mutations were responsible for broad antibiotic resistance [5]. In our study with relatively low number of patients included, we observed $20(20 / 60 ; 33.3 \%)$ TB isolates with embB306 mutations. Of those 20 MT isolates that harboured embB306 mutations, four $(4 / 20 ; 20.0 \%)$ TB isolates that were phenotypically susceptible to EMB, remaining $16(16 / 20 ; 80.0 \%)$ TB isolates were phenotypically resistant to EMB.

Overall, this study describes the first utilization of Ion Torrent sequencing of full-length genes to characterize drug resistant MT isolates for In conclusion, genotypic DST using Ion Torrent semiconductor NGS has the potential to provide useful information several weeks before phenotypic DST results. Therefore, genetic sequencing (NGS) seems to be a valuable tool for surveillance of drug resistance in TB. Before this takes place, there is a need to standardise the whole procedure including DNA extraction, recording, and reporting and data interpretation.

\section{Acknowledgements}

The authors of this paper would like to thank Cveta Vragoterova from National Laboratory for Mycobacteria (Institute for Pulmonary Diseases and Tuberculosis Skopje, North Macedonia) for allowance and contribution of Macedonian TB isolates in our study.

\section{References}

1. Cegielski J.P., Kurbatova E., van der Walt M., Brand J., Ershova J., Tupasi T., Caoili J.C., Dalton T., Contreras C., Yagui M., Bayona J., Kvasnovsky C., Leimane V., Kuksa L., Chen M.P., Via L.E., Hwang S.H., Wolfgang M., Volchenkov G.V., Somova T., Smith S.E., Akksilp S., Wattanaamornkiet W., Kim H.J., Kim C.K., Kazennyy B.Y., Khorosheva T., Kliiman K., Viiklepp P., Jou R., Huang A.S., Vasilyeva I.A., Demikhova O.V.; Global PETTS Investigators, Lancaster J., Odendaal R., Diem L., Perez T.C., Gler T., Tan K., Bonilla C., Jave O., Asencios L., Yale G., Suarez C., Walker A.T., Norvaisha I., Skenders G., Sture I., Riekstina V., Cirule A., Sigman E., Cho S.N., Cai Y., Eum S., Lee J., Park S., Jeon D., Shamputa I.C., Metchock B., Kuznetsova T., Akksilp R., Sitti W., Inyapong J., Kiryanova E.V., Degtyareva I., Nemtsova E.S., Levina K., Danilovits M., Kummik T., Lei Y.C., Huang W.L., Erokhin V.V., Chernousova L.N., Andreevskaya S.N., Larionova E.E., Smirnova T.G. Multidrug-resistant tuberculosis treatment outcomes in relation to treatment and initial versus acquired second-line drug resistance. Clin. Infect. Dis., 2016, vol. 62, no. 4, pp. 418-430.

2. European Centre for Disease Prevention and Control. Molecular typing for surveillance of multidrug-resistant tuberculosis in the EU/EEA - January 2016. Stockholm: ECDC, 2016.

3. European Centre for Disease Prevention and Control/WHO Regional Office for Europe. Tuberculosis surveillance and monitoring in Europe 2018. 2016 data. 206 p. URL: https://www.ecdc.europa.eu/sites/portal/files/documents/ecdc-tuberculosis-surveillancemonitoring-Europe-2018-19mar2018.pdf

4. Global tuberculosis report 2017. Geneva: World Health Organization, 2017. 295 p. URL: https://apps.who.int/iris/bitstream/hand le/10665/329368/9789241565714-eng.pdf?ua=1

5. Hazbón M.H., Bobadilla del Valle M., Guerrero M.I., Varma-Basil M., Filliol I., Cavatore M., Colangeli R., Safi H., Billman-Jacobe H., Lavender C., Fyfe J., García-García L., Davidow A., Brimacombe M., León C.I., Porras T., Bose M., Chaves F., Eisenach K.D., Sifuentes-Osornio J., Ponce de León A., Cave M.D., Alland D. Role of embB codon 306 mutations in Mycobacterium tuberculosis revisited: a novel association with broad drug resistance and IS6110 clustering rather than ethambutol resistance. Antimicrob. Agents Chemother., 2005, vol. 49, no. 9, pp. 3794-3802. doi: 10.1128/AAC.49.9.3794-3802.2005 
6. Hazbón M.H., Brimacombe M., Bobadilla del Valle M., Cavatore M., Guerrero M.I., Varma-Basil M., Billman-Jacobe H., Lavender C., Fyfe J., García-García L., León C.I., Bose M., Chaves F., Murray M., Eisenach K.D., Sifuentes-Osornio J., Cave M.D., Ponce de León A., Alland D. Population genetics study of isoniazid resistance mutations and evolution of multidrug-resistant Mycobacterium tuberculosis. Antimicrob. Agents. Chemother., 2006, vol. 50, no. 8, pp. 2640-2649. doi: 10.1128/ AAC.00112-06

7. Kim S.Y., Park Y.J., Kim W.I., Lee S.H., Ludgerus Chang C., Kang S.J., Kang C.S. Molecular analysis of isoniazid resistance in Mycobacterium tuberculosis isolates recovered from South Korea. Diagn. Microbiol. Infect. Dis., 2003, vol. 47, no. 3, pp. $497-502$.

8. Mokrousov I., Otten T., Vyshnevskiy B., Narvskaya O. Detection of embB306 mutations in ethambutol-susceptible clinical isolates of Mycobacterium tuberculosis from Northwestern Russia: implications for genotypic resistance testing. J. Clin. Microbiol., 2002, vol. 40, no. 10, pp. 3810-3813.

9. Park J., Jang W., Kim M., Kim Y., Shin S.Y., Park K., Kim M.S., Shin S.J. Molecular drug resistance profiles of Mycobacterium tuberculosis from sputum specimens using ion semiconductor sequencing. Microbiol. Methods, 2018, vol. 145, pp. 1-6. doi: 10.1016/j. mimet. 2017

10. Park J., Shin S.Y., Kim K., Park K., Shin S., Ihm C. Determining Genotypic Drug Resistance by Ion Semiconductor Sequencing With the Ion AmpliSeq ${ }^{\mathrm{TM}}$ TB Panel in Multidrug-Resistant Mycobacterium tuberculosis Isolates. Ann. Lab. Med., 2018, vol. 38, no. 4, pp. 316-323. doi: 10.3343/alm.2018.38.4.316

11. Sandgren A., Strong M., Muthukrishnan P., Weiner B.K., Church G.M., Murray M.B. Tuberculosis drug resistance mutation database. PLoS Med., 2009, vol. 6, no. 2: e2. doi: 10.1371/journal.pmed.1000002

12. Seifert M., Catanzaro D., Catanzaro A., Rodwell T.C. Genetic mutations associated with isoniazid resistance in Mycobacterium tuberculosis: a systematic review. PLoS One, 2015, vol. 10, no. 3: e0119628. doi: 10.1371/journal.pone.0119628

13. Somerville W., Thibert L., Schwartzman K., Behr M. A. Extraction of Mycobacterium tuberculosis DNA: a question of containment. J. Clin. Microbiol., 2005, vol. 43, pp. 2996-2997. doi: 10.1128/JCM.43.6.2996-2997.2005

14. Unissa A.N., Subbian S., Hanna L.E., Selvakumar N. Overview on mechanisms of isoniazid action and resistance in Mycobacterium tuberculosis. Infect. Genet. Evol., 2016, vol. 45, pp. 474-492. doi: 10.1016/j.meegid.2016.09.004

15. Zaw M.T., Emran N.A., Lin Z.J. Mutations inside rifampicin-resistance determining region of rpoB gene associated with rifampicin-resistance in Mycobacterium tuberculosis. Infect. Public. Health., 2018, vol. 11, no. 5, pp. 605-610. doi: 10.1016/j. jiph.2018.04.005

16. Zignol M., Cabibbe A.M., Dean A.S., Glaziou P., Alikhanova N., Ama C., Andres S., Barbova A., Borbe-Reyes A., Chin D.P., Cirillo D.M., Colvin C., Dadu A., Dreyer A., Driesen M., Gilpin C., Hasan R., Hasan Z., Hoffner S., Hussain A., Ismail N., Kamal S.M.M., Khanzada F.M., Kimerling M., Kohl T.A., Mansjö M., Miotto P., Mukadi Y.D., Mvusi L., Niemann S., Omar S.V., Rigouts L., Schito M., Sela I., Seyfaddinova M., Skenders G., Skrahina A., Tahseen S., Wells W.A., Zhurilo A., Weyer K., Floyd K., Raviglione M.C. Genetic sequencing for surveillance of drug resistance in tuberculosis in highly endemic countries: a multi-country population-based surveillance study. Lancet. Infect. Dis., 2018, vol. 18, no. 6, pp. 675-683. doi: 10.1016/ S1473-3099(18)30073-2

\section{Авторы:}

Содья Э., кандидат наук, научный сотрудник Национальной микобактериологической референс-лабораторией, Университетская клиника респираторных и аллергических заболеваний, Голник, Словения;

Топлак Н., кандидат наук, специалист в области молекулярной биологии, научная группа Omega d.o.o., Любляна, Словения; Корен С., кандидат наук, менеджер Life Science Perkin Elmer и научной группы Omega d.o.o., Любляна, Словения; Ковач М., кандидат наук, менеджер по продажам Thermo Fisher Scientific и научной группы Omega d.o.o., Любляна, Словения; Труден С., магистр, специалист Национальной микобактериологической референс-лаборатории Университетская клиника респираторных и аллергических заболеваний, Голник, Словения;

Жолнир-Довч М., кандидат наук, зав. Национальной микобактериологической референс-лабораторией, Университетская клиника респираторных и аллергических заболеваний, Голник, Словения.

\section{Authors:}

Sodja E., PhD, Research Associate, National Reference Laboratory for Mycobacteria, University Clinic of Respiratory and Allergic Diseases Golnik, Golnik, Slovenia;

Toplak N., PhD, Field Application Specialist for Molecular Biology, Research Team of Omega d.o.o., Ljubljana, Slovenia

Koren S., PhD, Manager of Life Science Perkin Elmer and Field Application Specialist, Research Team of Omega d.o.o., Ljubljana, Slovenia;

Kovač M., PhD, Manager of Thermo Fisher Scientific Sales Team and Research Team of Omega d.o.o., Ljubljana, Slovenia; Truden S., MSc, Analytics, National Reference Laboratory for Mycobacteria, University Clinic of Respiratory and Allergic Diseases Golnik, Golnik, Slovenia;

Žolnir-Dovč M., PhD, Head of National Reference Laboratory for Mycobacteria, University Clinic of Respiratory and Allergic Diseases Golnik, Golnik, Slovenia. 